by Jamileh Vasheghani Farahani ${ }^{1}$ and Mehdi Zaré ${ }^{2}$

\title{
Seismological aspects of the Varzeghan twin Earthquakes on 11 August 2012 (Mw 6.3 and Mw 6.1), in East Azerbaijan province, NW Iran
}

\author{
${ }^{1}$ Institute of Geophysics, University of Tehran, Tehran, Iran.E-mail: J_farahani@ut.ac.ir \\ ${ }^{2}$ International Institute of Earthquake Engineering and Seismology, Tehran, Iran
}

Two earthquakes occurred in the east Azerbaijan province of $N W$ Iran with $M w 6.3$ at 12:23:15.9 and $M w$ 6.1; 11 minutes after the first shock at 12:34:34.8 GMT time on 11 August 2012. The epicenters of the earthquakes were determined using seismograms recorded by the International Institute of Earthquake Engineering and Seismology (IIEES) broadband stations. We obtained their focal mechanisms and also calculated their seismic moments and moment magnitudes based on the source spectrum of these recordings. Other source parameters such as, stress drops, corner frequencies and Kappa $_{\text {(ave) }}$ were determined for earthquakes by the $S$-wave spectra using a model-fitting approach from the near stations. The maximum intensity of the earthquakes was determined as VIII+ on the EMS98 scale in Varzeghan and affected villages.

\section{Introduction}

The Tabriz region is located in the Araxes structural block of northwestern Iran, southwest of the continuation of the western Alborz Mountains toward the Caucasus. The epicenters of the twin earthquakes of 12 August 2012 are located in a region in west of Ahar, at a distance of $60 \mathrm{~km}$ NE Tabriz. Historical studies in Tabriz and the surrounding area show that Tabriz city has a history of destructive earthquakes. It has been devastated several times in the past. Two earthquakes occurred in 11 August 2012 NW Iran, in the Ahar region. The earthquakes approximately killed 306, injured 3037 and left 30000 people homeless, based on the Iranian health minister's statement of 13 August 2012. We located the epicenters of the earthquakes using seismograms recorded by Broadband Iranian Network (BIN). The first event occurred at 12:23:15.9 GMT time and the second at 12:34:34.8. Table 1a shows the estimates of the hypocentral location of the two events by the Iranian Seismological Center (IRSC) and the present study.

The Iranian Seismological Center (IRSC) at the Institute of Geophysics of the University of Tehran reports earthquake magnitudes using the corrected Nuttli (1973) magnitude scale (Rezapour, 2005):

$$
\mathrm{Mn}=\log \left(\frac{\mathrm{v}}{4 \pi}\right)+1.66 \log (\mathrm{d})-0.1 \quad \mathrm{~d} \leq 106 \mathrm{~km}
$$

$$
\mathrm{Mn}=\log \left(\frac{\mathrm{v}}{4 \pi}\right)+2.50 \log (\mathrm{d})-1.8 \quad 106>\mathrm{d} \leq 600
$$

where $v$ is the maximum amplitude in $\mathrm{nm} \mathrm{s}^{-1}$, and $d$ is the epicentral distance in $\mathrm{km}$. There were 494 aftershocks in the zone with $M \geq 2.5$ recorded by Broadband Iranian Network (BIN). In the present study, we analyze the 11 August 2012 earthquakes and review the seismicity in the last century within the limits of $36.5^{\circ}$ and $39.5^{\circ} \mathrm{N}$ latitude; and $45.0^{\circ}$ and $48.5^{\circ} \mathrm{E}$ longitude. The earthquakes' source parameters are obtained from spectral studies.

\section{Seismotectonic Setting}

The Varzeghan twin earthquakes occurred in the East Azerbaijan range of northeast Iran. This region is located within the seismotectonic area of Alborz - Azerbaijan, located west of the Caspian Sea, south of Caucasus thrust belt, east of Anatolia and north of Zagros mountain range. The earth's crust in northwest of Iran is deformed within a tectonic intersection zone, which is very seismically active. The geodetic and ancient seismology data, as well as scattering patterns of active deformation events, are evidence of high seismicity potential in the East Azerbaijan ranges (Geology Survey of Iran, 2012). Active tectonic movements in this range, as in other parts of Iran, result from the convergence of Arabia and Eurasia plates.

The major faults in the area surrounding the epicenter of the Varzeghan twin earthquakes include the North Tabriz fault, Ahar fault and Bozghoush fault. The North Tabriz fault is a complex structure with NW-SE trend, having a right lateral strike-slip mechanism (Berberian and Yeats, 1999). This basement fault is active and has an apparent outcrop on the surface. While seismically inactive for about two centuries, the North Tabriz fault earlier caused devastating seismic events including the 1641 TabrizDehkharqan earthquake (Ms=6.8), 1721 South-East Tabriz earthquake $(\mathrm{Ms}=7.3)$ and 1780 Tabriz earthquake $(\mathrm{Ms}=7.4)$ (Berberian and Yeats, 1999).

With an approximate east-west direction and a length of about 60 $\mathrm{Km}$, the Ahar fault is located to the north of Sabalan Volcano. The fault can be categorized geometrically in 3 parts: north-west, central and southeast. The fault zone of north and south of Bozghoush is the eastern termination of the North Tabriz fault and consists of the North Bozghoush and South Bozghoush faults with an approximate eastwest trend on the north and south sides of Bozghoush heights (Geology Survey of Iran, 2012). 


\section{Instruments and data}

Data for the twin earthquakes of NW Iran on 11August 2012 (Mw 6.3 and Mw 6.1) were recorded by IIEES using Guralp CMG-3TD instruments. 16 stations of the BIN (Broadband Iranian Network) were useful, and had suitable signal to noise ratios. Coordinates of the stations used for determining the location and focal mechanism of the earthquakes are listed in Table $1 \mathrm{~b}$. The earthquakes were located using SEISAN software (Havskov and Ottemoller, 2005).

\section{Causative fault}

The Varzeghan earthquakes caused ground surface rupture. The causative fault is assessed to be the South Ahar fault, having an east-west trend and a length of about $60 \mathrm{~km}$. The surface rupture of the Varzeghan fault was surveyed along about $4 \mathrm{~km}$ of ground surface by the investigating team and is located $13 \mathrm{~km}$ south of Varzeghan. Its Azimuth is N 245-260 degrees, as shown on Figure 1. Figures 2a, $\mathrm{b}$ also show the surface rupture near the Tabriz-Varzeghan road.

\section{Focal depth}

The focal depth of the earthquakes were reported to be 10 and 11 $\mathrm{km}$ respectively by the USGS (2012; http://www.usgs.gov) and 12.6 and $18 \mathrm{~km}$ by Harvard University (Harvard, 2012; http:// www.globalcmt.org/CMTsearch.html). The field observations and analysis of macroseismic data indicate a shallow depth for the both the earthquakes. A preliminary analysis of the location of the recorded strong ground-motion data in the present study also suggests a focal
Table 1. a. Hypocentral location, b. Station Coordinates

\begin{tabular}{|c|c|c|c|c|}
\hline \multicolumn{5}{|c|}{ (a) Hypocentral location } \\
\hline $\begin{array}{l}\text { Latitude N } \\
\text { (degrees) }\end{array}$ & $\begin{array}{c}\text { Longitude E } \\
\text { (degrees) }\end{array}$ & Magnitude & $\begin{array}{c}\text { Depth } \\
(\mathrm{km})\end{array}$ & Reference \\
\hline 38.5 & $46.9 \mathrm{I}$ & $6.2\left(\mathrm{M}_{\mathrm{n}}\right)$ & 10 & IRSC \\
\hline 38.4 & 46.8 & $6.0\left(M_{n}\right)$ & 4 & IRSC \\
\hline 38.529 & 46.841 & $6.3\left(\mathrm{M}_{\mathrm{w}}\right)$ & 16 & Present study \\
\hline 38.525 & 46.787 & $6.1\left(\mathrm{M}_{\mathrm{w}}\right)$ & 14.1 & Present study \\
\hline \multicolumn{5}{|c|}{ (b) Station Coordinates } \\
\hline Station & Latitude & Longitude & $\begin{array}{l}\text { Altitude } \\
\text { (m) }\end{array}$ & Name \\
\hline ASAO & $3432.88 \mathrm{~N}$ & $5001.52 \mathrm{E}$ & 2217 & Ashtian \\
\hline BJRD & $3741.98 \mathrm{~N}$ & $5724.49 \mathrm{E}$ & 1337 & Bojnoord \\
\hline $\mathrm{CHTH}$ & $3554.48 \mathrm{~N}$ & $5107.56 \mathrm{E}$ & 2250 & Charan \\
\hline GHVR & $3428.80 \mathrm{~N}$ & 5114.72E & 0927 & Qom \\
\hline GRMI & $3848.59 \mathrm{~N}$ & $4753.63 \mathrm{E}$ & 1300 & Germi \\
\hline KHMZ & $3344.38 \mathrm{~N}$ & $4957.85 \mathrm{E}$ & 1985 & Khomein \\
\hline MAKU & $3921.29 \mathrm{~N}$ & $4441.00 \mathrm{E}$ & 1730 & Maku \\
\hline MRVT & $3739.56 \mathrm{~N}$ & $5605.36 \mathrm{E}$ & 0870 & Maraveh tapeh \\
\hline NASN & $3247.95 \mathrm{~N}$ & $5248.50 \mathrm{E}$ & 2800 & Naein \\
\hline SHGR & $3206.50 \mathrm{~N}$ & $4848.08 \mathrm{E}$ & 0150 & Shushtar \\
\hline SHRT & $3338.77 \mathrm{~N}$ & $6017.46 \mathrm{E}$ & 0837 & Shah-rakht \\
\hline SNGE & $3505.55 \mathrm{~N}$ & $4720.82 \mathrm{E}$ & 1940 & Sanandaj \\
\hline TABS & $3338.94 \mathrm{~N}$ & $5707.14 \mathrm{E}$ & 0000 & Tabas \\
\hline THKV & $3554.94 \mathrm{~N}$ & $5052.73 \mathrm{E}$ & 1795 & Kavosh \\
\hline ZNJK & $3640.25 \mathrm{~N}$ & $4841.11 \mathrm{E}$ & 2200 & Zanjan \\
\hline
\end{tabular}

depth of 16 and $14 \mathrm{~km}$. Also, field observations from the region by Zare (2012) in the first week after the twin main shocks supported the view that they were shallow earthquakes.

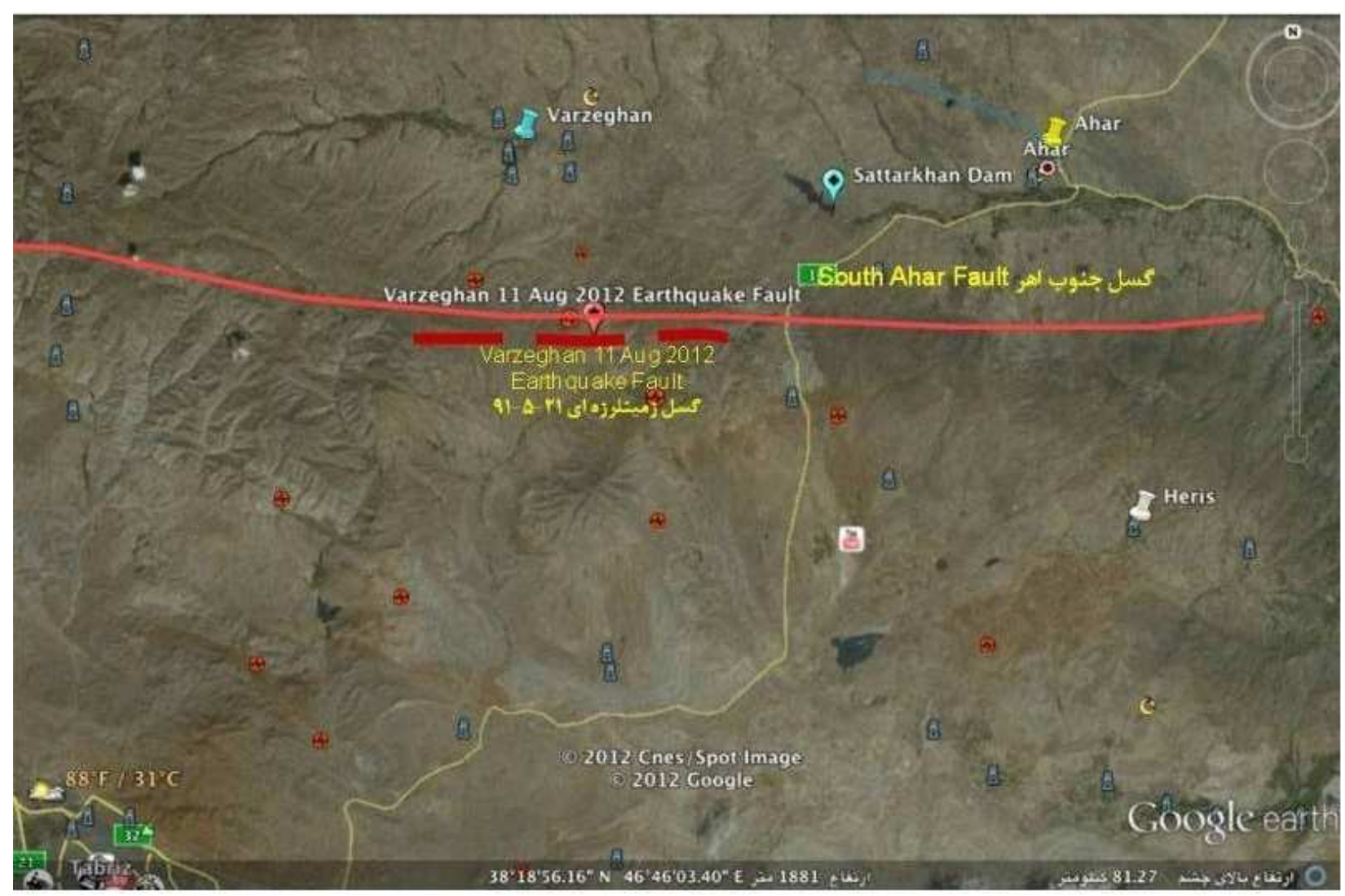

Figure 1. Surface faulting trend of the Varzeghan fault along the outcrop of South Ahar fault. 

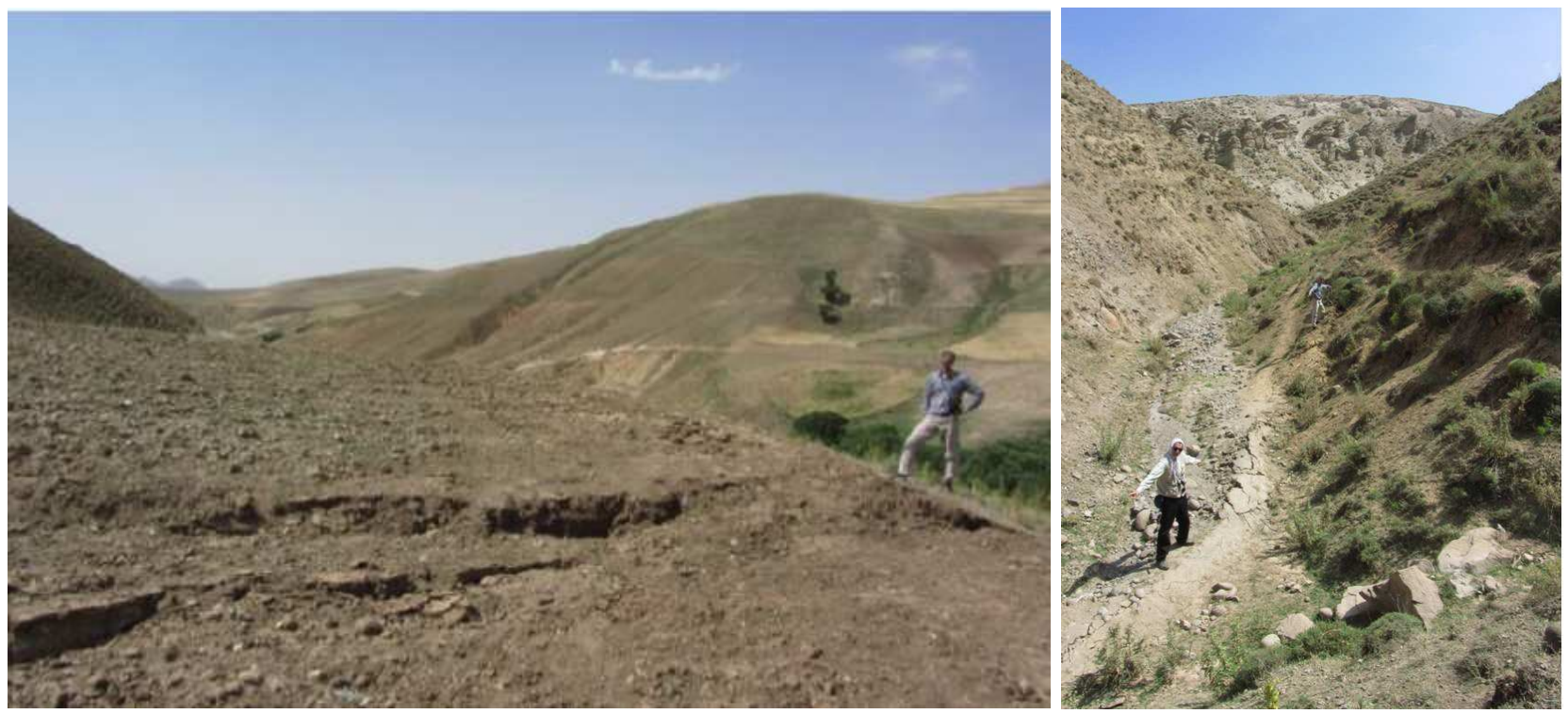

Figure 2. Surface rupture on the Varzeghan twin earthquakes fault (Zaré, 2012).

\section{Seismic catalogue and local Mechanism}

Instrumental seismicity of the region recorded in Broadband Iranian Network (BIN) shows that until 30 March 2013 more than 810 seismic events of $M \geq 2.5$ have occurred in the region. Figure 3 shows seismicity of Eastern Azerbaijan from 2012/08/11 to 2013/03/ 30 from these aftershocks.

The focal mechanism of the two events on 11 August 2012 in the Ahar region were obtained using recorded $\mathrm{P}$-wave first motions from the IIEES seismograms and FOCMEC software (Havskov and Ottemoller, 2005). The focal mechanisms of both events show

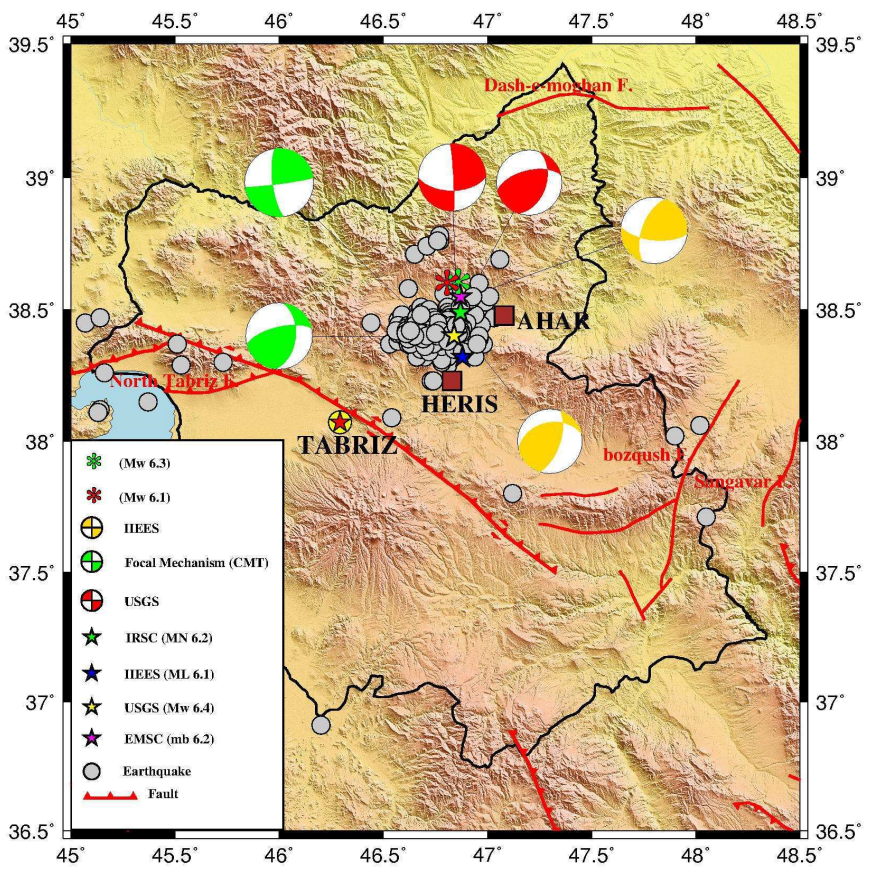

Figure 3. Main shock epicenter estimates, reported by different agencies and this study (with IIEES Data), their focal mechanisms and distribution of aftershocks of the 2012 Varzeghan twin earthquakes. right-lateral strike-slip faulting on E-W trending fault, parallel to the aftershocks and the trend of the South Ahar fault (Figure 3). Besides, in this study, we identified a considerable reverse component for the second main shock, $\mathrm{Mw}=6.1$, which is consistent with a CMT solution and work at Harvard University (http:// www.globalcmt.org/CMTsearch.html) and the USGS (http:// www.usgs.gov). The field observations also revealed the existence of an E-W trending right-lateral strike-slip surface rupture (Figure 4). Study of records of seismicity (Table 2) shows that the historical earthquakes of this area are part of the historical earthquakes of Tabriz region, the most important of which was that of 1780 in Tabriz. In the epicentral zone of the Varzeghan twin earthquakes, no severe earthquake was reported during approximately the past 1300 years for which documentary records exist (Ambraseys and Melville, 1982).

The instrumental seismicity of the region shows that nearly 810 seismic events have been recorded during the past century. The seismicity of the region is presented in Figure 5. In addition, we present an Ahar map in Figure 6. This shows the E-W trending South Ahar fault, which seems to be the causative fault responsible for the Varzeghan earthquakes. The inferred fault zone is marked by dashed lines on a part of Ahar geological map (1:250000).

\section{Major earthquakes in the region before 1900}

The seismic history of Tabriz shows that region has experienced active seismicity since 634 A.D., but there is no macroseismic information. The earthquakes were strong enough to destroy Tabriz several times (Berberian and Arshadi, 1977). Several major destructive earthquakes have occurred in Tabriz, the most important of which occurred in 634, 1441, 1522 and 1780 (Eprikian, 1903). The Tabriz earthquake in 634 was reported by Adjemian (1937), MoazamiGoudarzi (1972) and Moazami-Goudarzi et al. (1972) [Berberian and Arshadi, 1976].

The North Tabriz Fault (NTF) is one of the active faults of NW Iran. Among the many historical earthquakes that occurred in the 


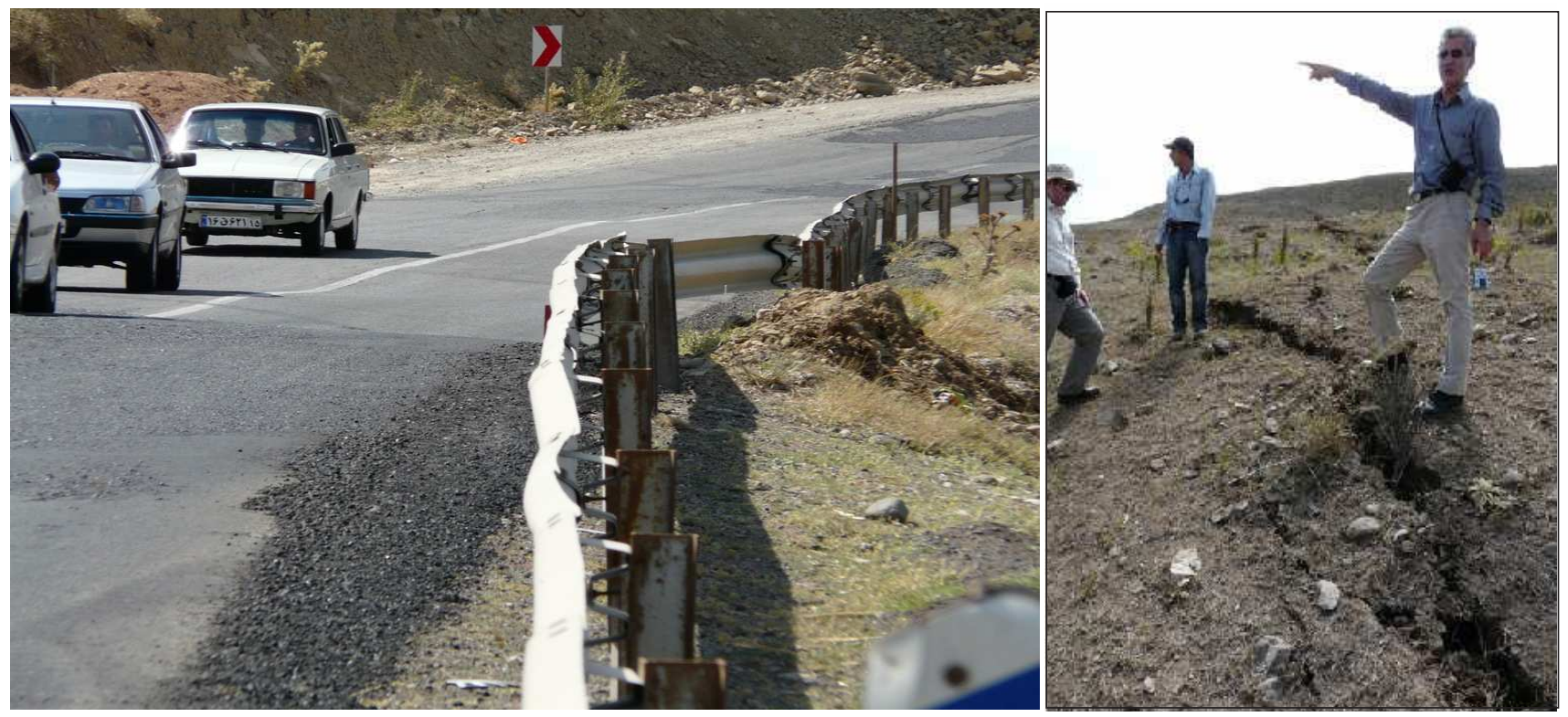

Figure 4. The appearance of the surface ruptures indicating right-lateral strike-slip faulting (Zaré,2012).

Tabriz region (e.g., the 858, 1042, 1273, 1304, 1550, 1641, 1717, 1721,1780 and 1786 earthquakes), the destructive earthquakes of 1042/11/04, 1721/04/26 and 1780/01/08 with Magnitudes of +7 were accompanied by coseismic surface faulting (Ambraseys and Melville, 1982; Berberian and Yeats, 1999). The 1780 earthquake ruptured in the northwest part of the NTF, whereas the 1721 event ruptured in the southeast part of the fault (Hessami et al, 2003).

We present the epicenters for some of the most important historical earthquakes in Figure 5. Based on the plotted seismicity for the $20^{\text {th }}$ century (Figure.5), a probable seismic gap can be identified in the central part of the North Tabriz Fault (NTF) based on comparisons of events reported during historic times (pre-1900) from this part of NTF.

\section{Intensity distribution}

The two relatively large shallow earthquakes that struck NW Iran, about 60 and $50 \mathrm{~km}$ northwest of Tabriz city, on 11 August 2012, caused about 306 deaths, 3037 injuries and 30000 homeless people (reported by the health minister of Iran).

These events caused panic in the cities of the epicentral region (especially in the cities of Ahar, Varzeghan, Kalibar, Heris, and in Tabriz which is the largest city in NW Iran). Panic among people caused them to settle outdoors in Tabriz and the other cities mentioned. The highest number of deaths reported were in Varzeghan city and "Baj e Baj", Gourdeh and Dino villages. The most severe damage was reported from the villages of Gourdeh, and Dino. The earthquake was also felt in other cities including Tabriz, Marand, Bostanabad, Soumahe Sara, Ardabil, Bukan, Astara, Khoy, Salmas, Parsabad Moghan, Shabestar, Meshkin Shahr, Rasht, Mahabad, Bonab, Urmia, Mamaghan, Hadishahr, Maraagheh, Meyaneh, Miandoab. Following the Varzeghan earthquakes, reconnaissance coverage of the area was made by a team from IIEES (Zaré et al, 2012). An effort was made to visit the entire region affected by the earthquake. According to results of these investigations, the maximum intensity was estimated to be VIII+ on the EMS98 scale in Varzeghan and affected villages, VII+ in Ahar city and VI+ in Heris city. The intensity of the earthquake in
Tabriz was V (Figure 7). From the view point of surface geology conditions, we studied the surface ruptures and ground fissures (based on the INQUA intensity scale, Michetti et al., 2003) and observed that the iso-intensity map concords with the geological evidence as well.

We here illustrate some examples of earthquake damage to buildings in the region of Azerbaijan. We used the European macroseismic scale 1998 to classify the types of structures. Based on EMS-98, classifications of damage were applied to masonry and reinforced concrete buildings (Grunthal, 1998) in order to determine the intensity level. In this study, for the shaken area, there were several types of houses and buildings. These include very weak building structures, with inferior building materials, that are dangerous to human occupants. These buildings are poorly designed and building material is very weak, so they have little resistance to a variety of

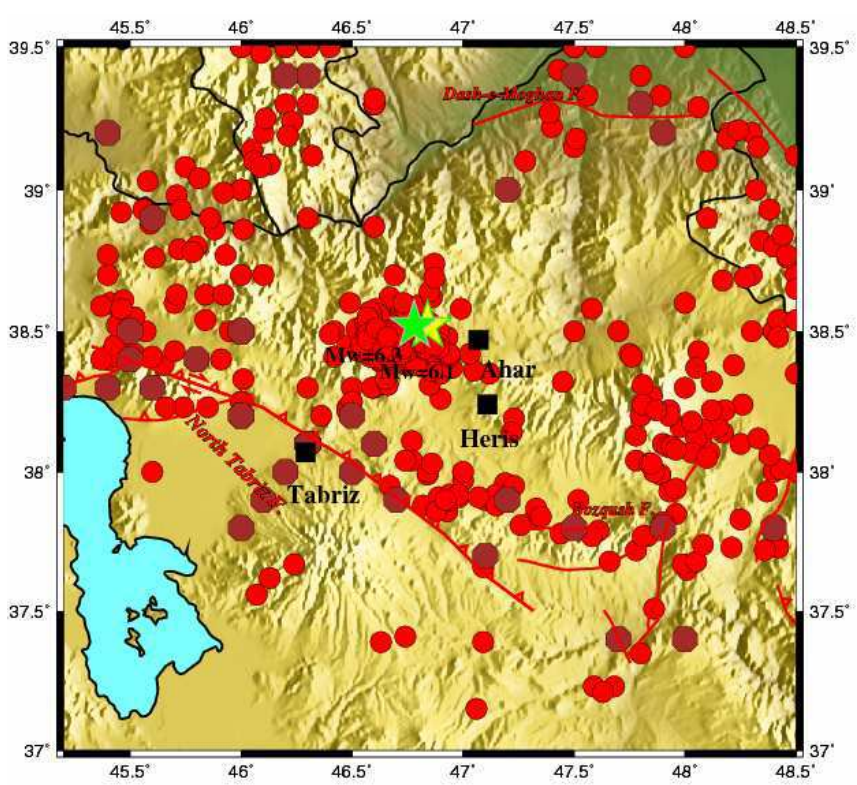

Figure 5. Seismicity of Eastern Azerbaijan in 1900-2013 (red circles) and historical seismicity of eastern Azerbaijan (brown hexagons). 

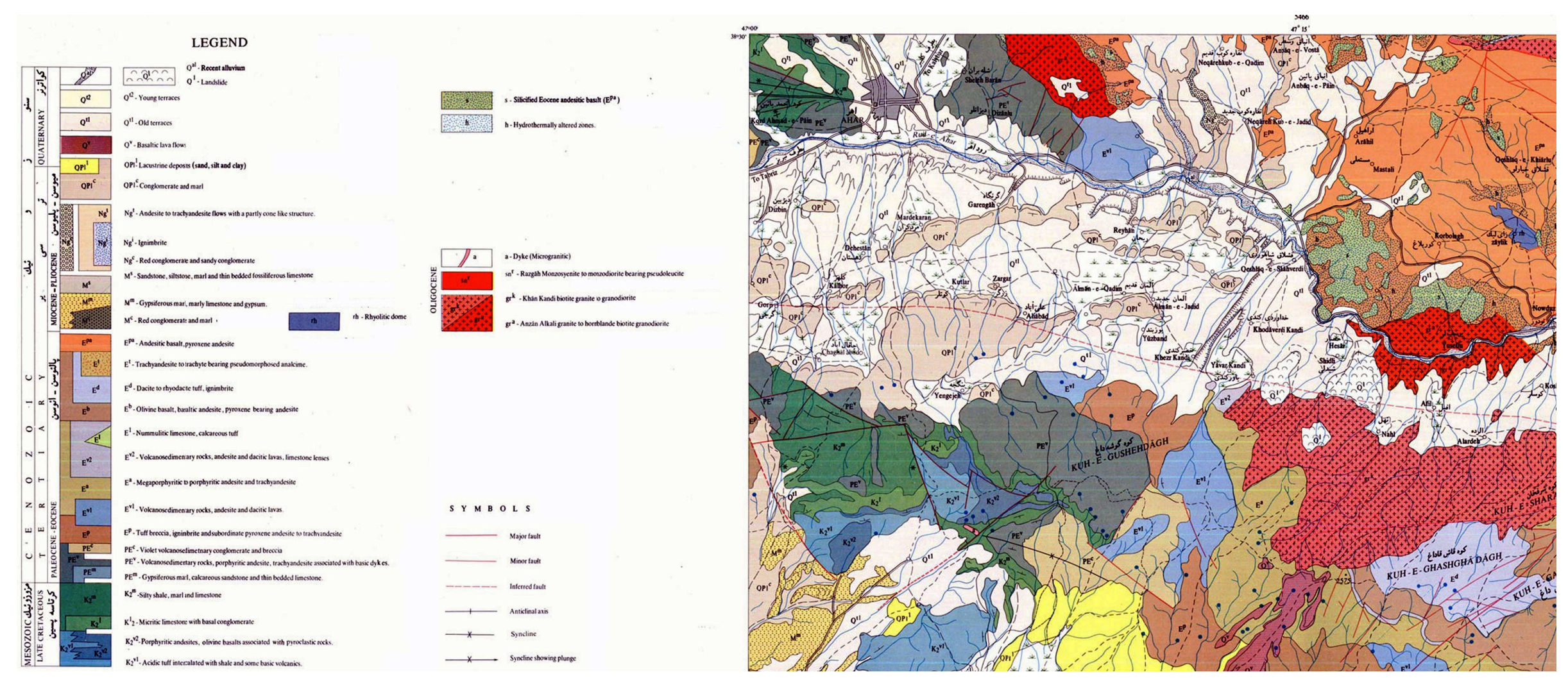

Figure 6. Part of the geological map (1:250000) of Ahar (Geological Survey of Iran, 2012). 


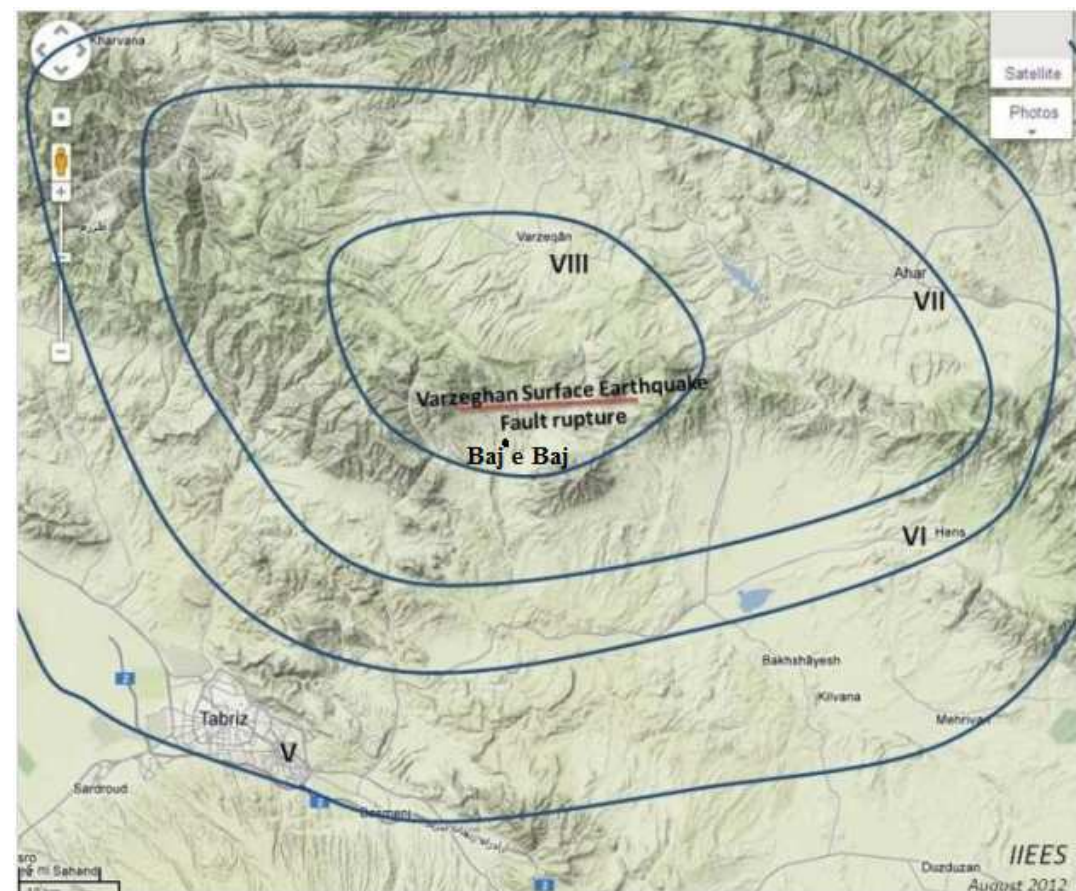

Figure 7. Isoseismal map of the Varzeghan earthquake (11 August 2012) from observations of IIEES reconnaissance team (Zaré, 2012).

vibrations. Based on observations in the region, numbers of very weak buildings existed in the macroseismic zone and, in villages, almost all buildings of this type totally collapsed (Figure 8a-8b). In these villages, most of the people were killed and others injured. Most of the buildings and houses were built of clay brick or masonry without reference to any technical standards. In these regions, the greatest damage was inflicted on traditional constructions. The main failure mode was the collapse of heavy roofs. Masonry buildings, for example in Figure $8 \mathrm{a}-8 \mathrm{~b}$ (very weak mortar), suffered very heavy structural damage with a damage grade (based on Grunthal, 1998) of five (destruction), total or near total collapse.

In Baj e Baj (a village with 40 victims and the most demolition in the epicentral region), most of the buildings were made of bricks and arched wood beam roofs, adobe and low-quality masonry materials. Most of the weak buildings suffered total damage and, as seen in Figure $8 \mathrm{c}-8 \mathrm{~d}$, some of them collapsed. Some of this type of building contained heavy materials and also, their problem were poor structural connections. In types of structure with simple stone masonry such as in Figure 8c-8d, some parts of the bearing walls failed and there was collapse of the roof and floor slabs. This kind of heavy structural damage is of damage grade is 4 .

Some facilities such as hospitals, universities, gas stations, roads and bridges were damaged in the earthquake-stricken area. We believe that sometimes, in such buildings, despite the advanced design of the structures, the construction and performance is usually poor.

In Heris city, a hospital was built on a hill slope one year before the 11 August 2012 earthquakes. Although, the city was located about $20 \mathrm{~km}$ away from the earthquake epicenter, the hospital was rendered out of service. This hospital (the main health center near the epicentral zone) was located 73 kilometers east of Tabriz, the capital city of the east Azerbaijan province (Figure 9a-9b). As a result, people in need of treatment were referred to a mobile hospital erected by the Ministry of Health or to hospitals in Tabriz. Figure 9 shows an example of damage to Heris hospital.

Moreover, there were some structures with large diagonal cracks in the walls or some cracks in the exterior wall in the twin Varzeghan earthquakes region. Figure 9c shows an example of these buildings that exhibited moderate structure damage of grade is 3 . In type of structure with many vertical cracks, such as Figure 9d, slight structural damage resulted and the damage was of grade two.

\section{Distribution of Earthquakes}

We mapped seismicity in the region with 810 earthquakes of $M>=2.5$ and 494 aftershocks detected by the BIN network between 11 August 2012 to 30 March 2013. The aftershocks and seismicity for 1900 to 2013 in the region are shown respectively in Figures 3 and 5 . The locations of the aftershocks were recorded by permanent stations of the BIN network. The figures show that the seismicity trace has a trend of nearly east-west in this area.

Figures $10 \mathrm{a}$ and $10 \mathrm{~b}$ show histograms of the magnitudes of earthquakes and aftershocks in the region. The distribution of earthquakes in Figure 10 shows non-cumulative frequency of magnitudes for 110 years (Figure 10a) and for the aftershocks during 7 months (Figure 10b). This figure shows that the distribution of frequency of aftershocks is representative of a maximum magnitude of $\mathrm{M}=6$ in the region. Before 1994 (when the regional seismograph

Table 2. Magnitude 5 and greater earthquakes within a $100 \mathrm{~km}$ radius of Varzeghan earthquake epicenter

\begin{tabular}{|c|c|c|c|c|c|c|c|}
\hline $\begin{array}{l}\text { Time } \\
\text { hh:mm:ss }\end{array}$ & $\begin{array}{l}\text { Date } \\
\text { M-Y-d }\end{array}$ & $\begin{array}{l}\text { Latitude N } \\
\text { (degrees) }\end{array}$ & $\begin{array}{l}\text { Longitude E } \\
\text { (degrees) }\end{array}$ & $\begin{array}{l}\text { FD } \\
(\mathrm{km})\end{array}$ & $\begin{array}{c}\text { Magnitue } \\
\text { mb Ms Mw ML }\end{array}$ & Reference & Region \\
\hline \multirow{3}{*}{18} & 858 & 38.100 & 46.300 & & 6.0 & $\mathrm{Am}$ & Tabriz \\
\hline & $11-1042-04$ & 38.100 & 46.300 & & 7.6 & Amb & Tabriz \\
\hline & 1598 & 37.800 & 47.500 & & 6.1 & Amb & Sarab \\
\hline 18 & $02-1641-05$ & 37.900 & 46.100 & & 6.8 & Amb & Dehkharghan \\
\hline 06 & $03-1717-12$ & 38.100 & 46.300 & & 5.9 & Amb & Tabriz \\
\hline 07 & $04-1721-26$ & 37.900 & 46.700 & & 7.7 & Amb & Tabriz \\
\hline 24 & $01-1780-08$ & 38.200 & 46.000 & & 7.7 & Amb & Tabriz \\
\hline 16 & $05-1861-24$ & 39.400 & 47.900 & & 6.0 & Amb & Tabriz \\
\hline 17 & $05-1883-03$ & 37.900 & 47.200 & & 6.2 & Amb & \\
\hline 0617 & 01-1905-09 & 38.000 & 46.000 & & 6.2 & Amb & \\
\hline 112442 & $12-1960-25$ & 39.500 & 47.500 & 33 & 5.0 & BAN & \\
\hline 160953 & $02-1965-10$ & 37.660 & 47.090 & 45 & 5.0 & ISC & Alikhalaj \\
\hline
\end{tabular}

AMB: Ambraseys and Melville (1982), ISC: International Seismological Center, UK, BAN= BANISADR, FD = Focal Depth 

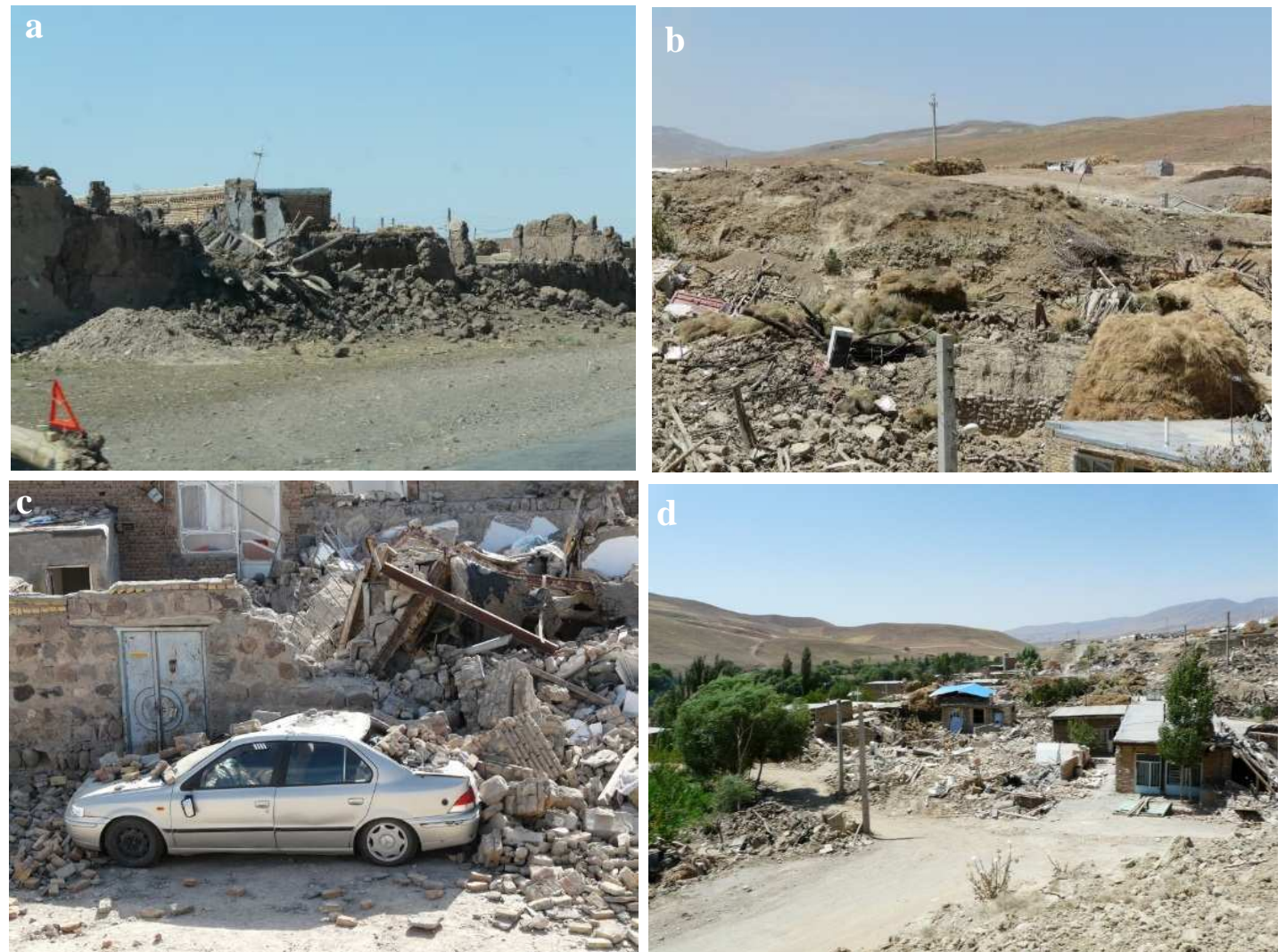

Figure 8. (a and b) Examples of total collapse in very weak buildings, (c and d). Examples of demolished buildings in Varzeghan (left-c) and Baj e Baj (right-d) (Zaré, 2012).
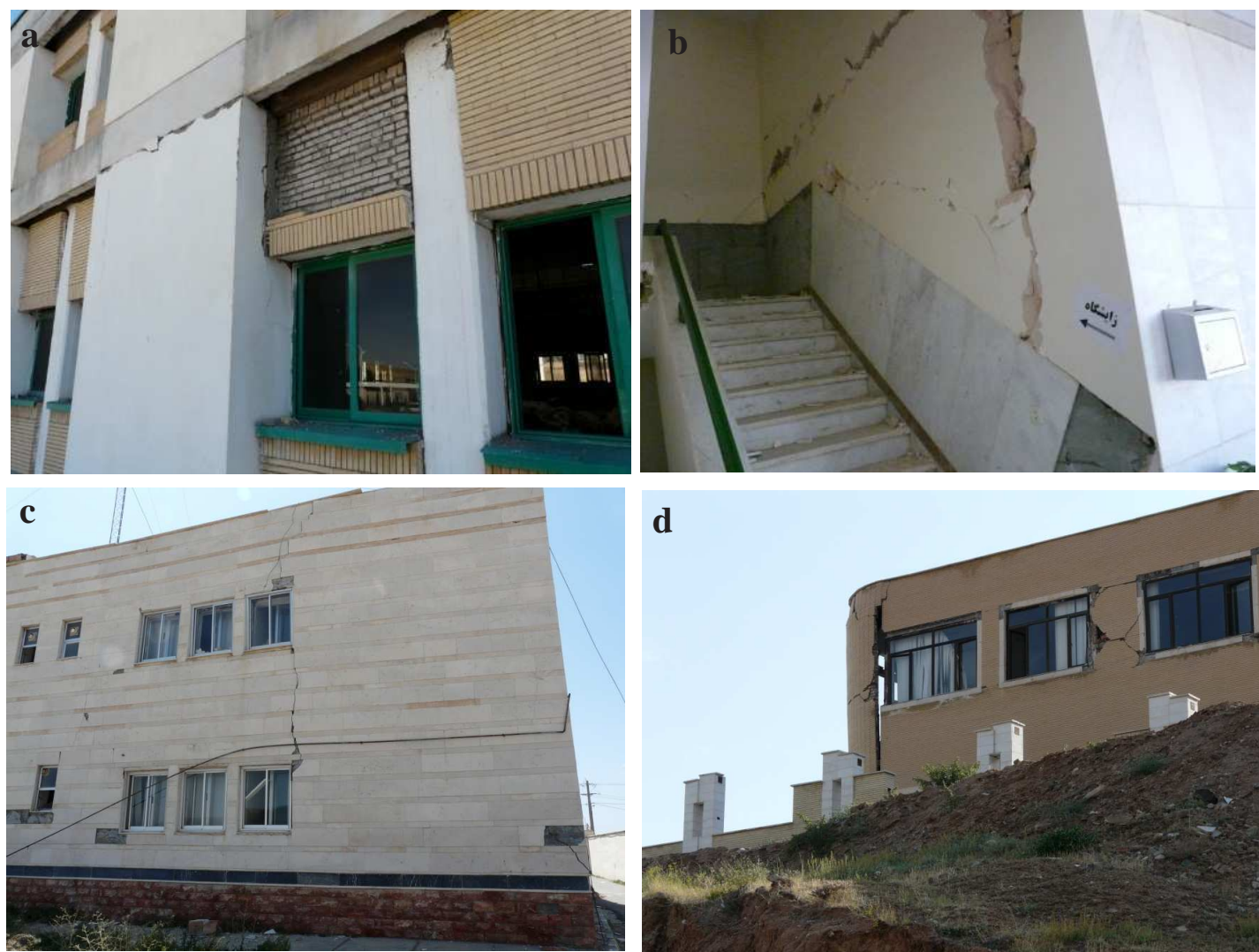

Figure 9. (a and b). Examples of Heris Hospital, ( $c$ and d). Example of diagonal cracks in walls, and of slight structural damage in the region, respectively (Zaré, 2012). 

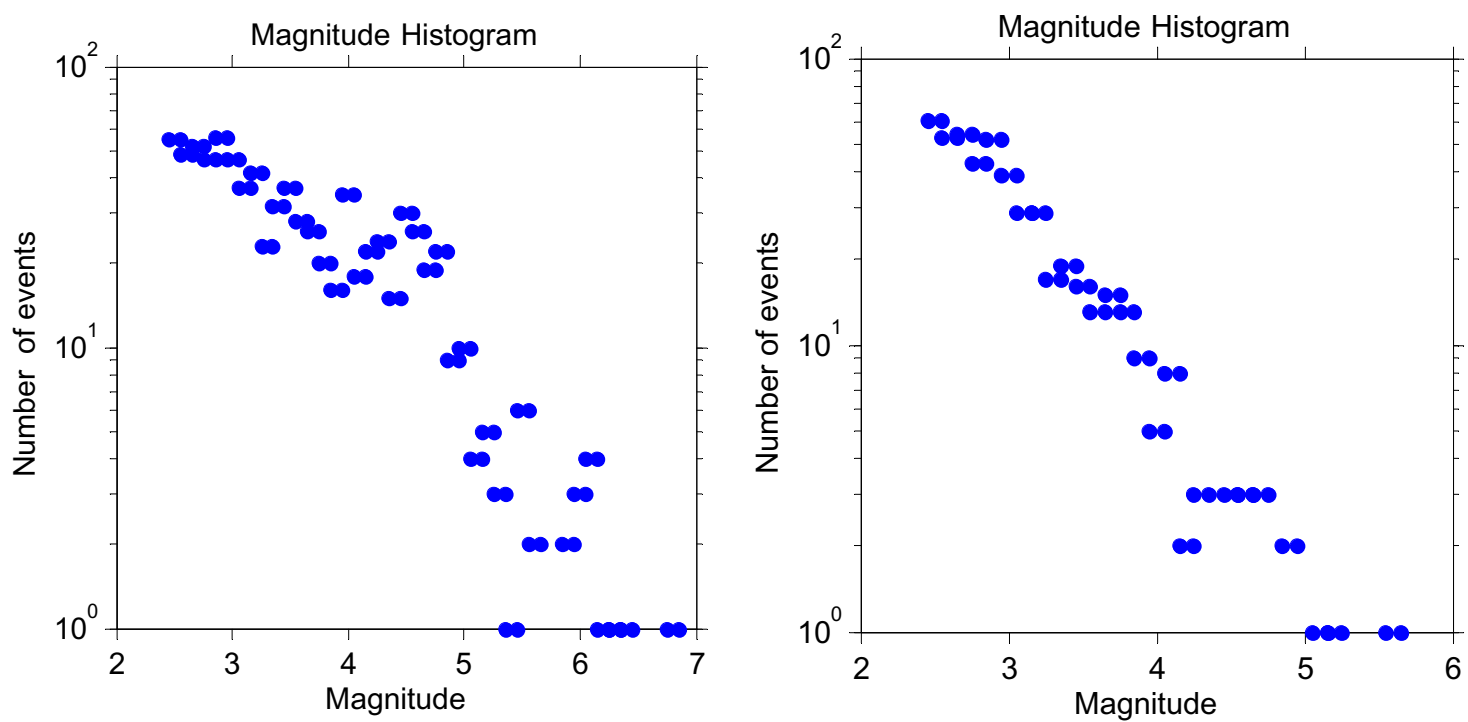

Figure 10. $a$ and $b$. The freuqency distribution of earthquake for 1900-2012 in Azerbaijan area (a), and The frequency distribution of earthquake magnitudes from 11 August 2012 to 30 March2013 in Azerbaijan area (b).

network of Azerbaijan was established and came into service), fewer events were recorded in the region. This might be partially related to the lack of enough seismographic stations throughout the region, or a partial seismic quiescence in the region. Thus, a reliable earthquake database exists only for the last couple of decades.

\section{Data and analysis of regional recordings}

We have attempted to use a spectrum fitting method (Shi et al., 1996, 1998) for determination of Varzeghan earthquakes source parameters. First, for minimizing the influence of noise, for the 22 stations of the BIN (Broadband Iranian Network) we obtained their signal to noise ratio for the whole of the signals. We selected 16 stations for examination of the first mainshock because they had good signal-to-noise ratios whereas the rest did not (their signal to-noise ratio was less than 2). We also corrected instrument response. The seismic moment was calculated from the low frequency spectral level $\Omega$ of the displacement for the regional analysis. We assumed the model of Brune (1970) in our analysis and estimated the source radius ro $=2.34 \mathrm{v} /(2 \pi \mathrm{fc})$ from the corner frequency (fc) from the S-wave. The static stress drop $\Delta \sigma$ was then estimated from the standard circular static crack solution (Eshelby, 1957; Brune, 1970), $\Delta \sigma=(7 / 16)\left(\mathrm{M}_{0} / \mathrm{r}^{3}\right)$. In our spectral analysis, we assumed $\mathrm{Q}(\mathrm{f})=140 \mathrm{f}^{0.90}$, also $\Delta \sigma$ determined $46-51$ bars, Kappa ${ }_{(\text {ave) }}=0.035$ for twin earthquakes from the near stations (GRMI and MAKU located in the epicentral distance of $\leq 200 \mathrm{~km}$ ) using trial and error. An example of this analysis is shown in Figure 11. The original velocity recordings come from station GRMI located $96.8 \mathrm{~km}$ away from the event. The left-hand figures in
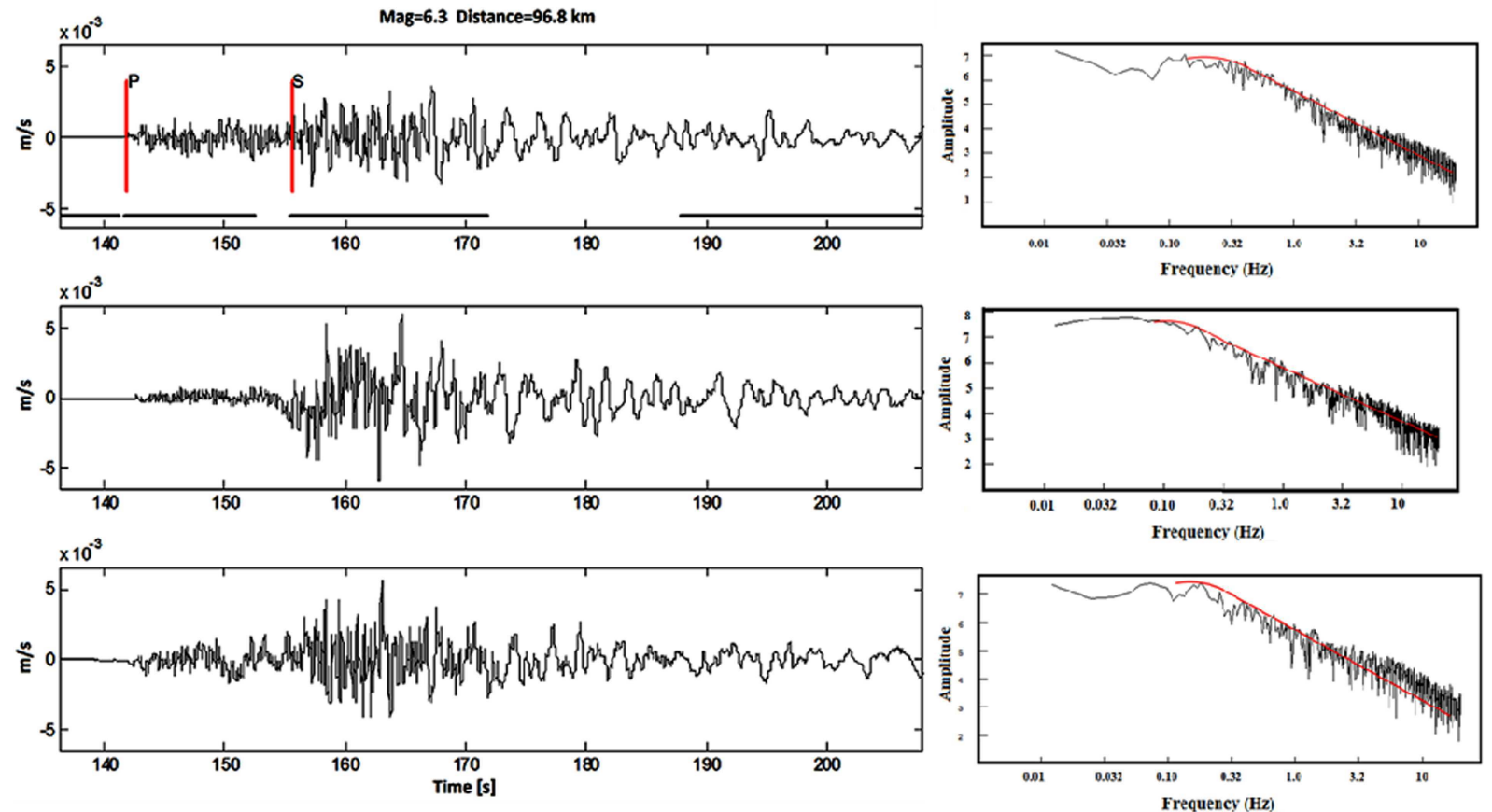

Figure 11 Typical example from a three component seismogram at station GRMI with Mw=6.3 and displacement spectra with the best fit w-square source at a distance of $96.8 \mathrm{~km}$. 
Figure 11 show the three-component ground motion recordings at this station, and the right-hand figures show displacement spectra with the best fit $\omega$-square source.The results related to the source parameters and radiated seismic energy is listed in Table $3 \mathrm{a}$.

Table 3

\begin{tabular}{|c|c|c|c|c|c|c|c|c|c|c|c|c|}
\hline & & & ur & aram & ters $\mathrm{fc}$ & $\mathrm{r} 11 \mathrm{Au}$ & ust 20 & 10 & hquak & & & \\
\hline $\begin{array}{l}\text { Lati } \\
\text { (de }\end{array}$ & $\begin{array}{l}\text { ude N } \\
\text { grees) }\end{array}$ & & $\begin{array}{l}\text { itude E } \\
\text { grees) }\end{array}$ & $\begin{array}{r}\text { Magn } \\
\text { (M }\end{array}$ & itude & $\begin{array}{c}\text { Depth } \\
(\mathrm{km})\end{array}$ & $\begin{array}{r}\mathrm{M}_{0} \\
(\mathrm{~N}-\mathrm{n}\end{array}$ & & $\begin{array}{l}\Delta \mathrm{E} \\
\text { (er }\end{array}$ & & $\begin{array}{c}\mathrm{Fc} \\
(\mathrm{Hz})\end{array}$ & $\begin{array}{c}\Delta \sigma \\
\text { (bar) }\end{array}$ \\
\hline & .529 & & 841 & 6. & & 16 & $3.56 \mathrm{E}$ & & $1.78 \mathrm{E}$ & +21 & 0.20 & 46 \\
\hline & .525 & & .787 & 6. & & 14.1 & $1.82 \mathrm{E}$ & & $8.91 \mathrm{E}$ & +20 & 0.26 & 51 \\
\hline & & ) $\mathrm{Fo}$ & $1 \mathrm{mech}$ & ism & form & ation of & he Varze & & earthc & uakes & & \\
\hline 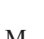 & Strike & Din & Role & Strik & Din & Pele & & axis & & & $T-a x$ & \\
\hline & & & & & & & Plunge & Azi & imuth & Plung & \begin{tabular}{l|l} 
ge & A
\end{tabular} & Azimuth \\
\hline 6.3 & 201 & 60 & 28 & 96 & 66 & 147 & 3 & & 149 & 40 & & 56 \\
\hline 6.1 & 19 & 64 & 56 & 256 & 41 & 139 & 13 & & 133 & 57 & & 243 \\
\hline
\end{tabular}

\section{Conclusion}

A preliminary analysis of instrumental data recorded by IIEES and field observations indicate the following results for the Varzeghan 2012 twin earthquakes.

The focal mechanism of the twin earthquakes at Varzegahn on 11 August 2012 was determined using seismograms recorded by the Broadband Iranian Network (BIN) of IIEES. We also calculated the seismic moment and moment magnitude based on the source spectrum of the records. The estimated moment magnitude for these earthquakes are Mw 6.3 and Mw 6.1; the maximum intensity was estimated to be VIII+ on the EMS98 scale in Varzeghan and affected nearby villages.

Based on our analysis of the location of earthquakes, the focal depths of the first and second shocks were determined 16 and $14 \mathrm{~km}$, respectively, indicating shallow earthquakes.

The South Ahar fault (Figure 6) had an E-W trend and a $60 \mathrm{~km}$ length. It is consistent with the focal mechanism obtained from the fault plane solutions of the causative fault of the earthquakes determined in this study and also by the USGS (www.usgs.gov) and Harvard University (www.globalcmt.org/CMTsearch.html) as shown in Figure 3. Therefore the causative fault was the South Ahar fault.

A review of the recorded seismicity for the $20^{\text {th }}$ century revealed a probable seismic gap in the central part of the North Tabriz Fault (NTF) in comparison with events reported during historic time (pre1900) from this part of NTF.

The results related to the focal mechanism and source parameters of the Varzeghan earthquakes are listed in Table $3 b$ and Table 3a.

\section{Data and Resources}

The waveform data and catalog for earthquakes from the Broadband Iranian Network (BIN) of the International Institute of Earthquake Engineering and Seismology (IIEES) were searched using http://www.iiees.ac.ir/, (last accessed March 2013).

\section{Acknowledgement}

The authors would like to express their gratitude to the International Institute of Earthquake Engineering and Seismology for the delivery of the recorded data. Also, thanks the colleagues in IIEES for their support during the field trips (specially to Drs. E. Haghshenas, A. Ansari) as well as for Eng. B. Esmaeili.

\section{References}

Adjemianh, H., 1937, Haik calendar, Tabriz, Iran (in Armenian).

Ambraseys, N.N. and Melville, C. P. 1982, A History of PersianEarthquakes. Cambridge Earth Science Series. Cambridge and New York: Cambridge University Press.

Brune, J., 1970 Tectonic stress and spectra of seismic shear waves from earthquakes. Journal Geophysical Research, v. 75, pp. 4997-5009.

Berberian, M. and Arshadi, S., 1976, On the evidence of the youngest activity of the North Tabriz Fault and the seismicity of Tabriz city. Geological Survey of Iran, v. 39, pp. 397-418.

Berberian, M. and Arshadi, S., 1977, The Shibli Rift System (Sahand region, NW Iran). Geological Survey of Iran, v. 40, pp. 229-236.

Berberian, M. and Yeats, R.S., 1999, Pattern of historical earthquake rupture in the Iranian Plateau. Bulletin Seismological Society of America, v. 89, pp. 120-139.

Eprikian, H., 1903, Bnashkarik Patkerazard Bararan (Illustrated dictionary of names and places; in Armenian), Venice.

Eshelby, J., 1957, The determination of the elastic field of an ellipsoidal inclusion, and related problems. Proceedings Royal Society of London, Seriea A, v. 241(1226), pp. 376-396.

Geological Survey of Iran, 2012, Preliminary report on the 11 August 2012, Ahar earthquakes (in Farsi).

Grunthal, G. 1998, European Macroseismic Scale 1998EMS-98. Chairman of the ESC Working Group "Macroseismic Scales" GeoForschungs Zentrum Potsdam, Germany.

Harvard University, 2012, http://www.globalcmt.org/CMTsearch.html

Havskov, J. and Ottemoller L., 2005, SEISAN: the earthquake analysis software for Windows, Solaris, Linux and Mac OS X,Version 8.1, http:// www.geociencias.unam.mx/ gomez/Curso_sismo/manual_seisan_8.1. pdf.

Hessami , K.D., Pantosti , H., Tabassi, E., Shabanian, M.R., Abbassi, Feghhi, K. and Solaymani, S., 2003, Paleoearthquakes and slip rates of the North Tabriz Fault, NW Iran: preliminary results. Annals of Geophysics, GEOPHYSICS, v. 46, pp. 903-915.

Michetti, A.M., Esposito, E., Mohammadioun, J., Mohammadioun, B., Gürpinar, A., Porfido, S., Rogozhin, E., Serva, L., Tatevossian, R., Vittori, E., Audemard, F., Comerci, V., Marco, S., McCalpin, J. and Morner, N.A., 2003, An innovative approach for assessing earthquake intensities: The proposed INQUA scale based on Seismically-Induced Ground effects in the environment. XVI INQUA Congress, Reno, July 23-30, 2003.

Moazami-Goudarzi, K., 1972, Seismology. Ministry of Higher Education, Publication No. 1, 470 p, Tehran (in Farsi).

Moazami-Goudarzi, K, Hossein-Javaheri. J and Hafizi, M.K, 1972, Seismic zoning of Tabriz. Journal of the Earth and Space Physics, Institute of Geophysics, Tehran University, v. 1(3), pp. 71-74.

Nuttli, O.W., 1973, Seismic wave attenuation relations for eastern North America. Journal of Geophysical Research, v. 78, pp. 855-876.

Rezapour, M (2005). Magnitude scale in the Tabriz seismic network. Journal of the Earth and Space Physics, v. 31(1), pp. 13-21.

Shi, J., Kim, W.Y. and Richards, P.G., 1996,Variability of crustal attenuation in the northeastern United States from Lg waves, Journal Geophysical Research, v. 101, pp. 25231-25242.

Shi, J., Kim, W.Y. and Richards, P.G., 1998, The corner frequencies and stress drops of intraplate earthquakes in the northeastern United States, Bulletin Seismological Society of America, v. 88, pp. 531-542.

USGS (2012) http://www.usgs.gov.

Zare, M., Kalantari, A., Ansari, A., Haghshenas, E., Davudi, M., Mostafazadeh, M., 2012, A preliminary reconnaissance report on the Varzaghan-Ahar twin earthquakes in East Azerbaijan province. International Institute of Earthquake Engineering and Seismology 1-13; http://www.iiees.ac.ir/ images/stories/EQBank/EQreport/ahar/IIEES.pdf (in Farsi).

Zare M. 2012, Personal Courtesy on Vazeghan, NW Iran; 12 August 2012 Twin Earthquakes. 